Holt, D. (2012), The Journey of a 'Green' Micro-Enterprise -The Green Planet. Corporate Social Responsibility and Environmental Management, 19(2), pp. 90-101

\title{
The journey of a 'green' micro-enterprise - The Green Planet
}

\section{Keywords}

\section{Diane Holt}

Environmental enterprises, small business, teaching case, retail

\begin{abstract}
This teaching case explores the longitudinal evolution of a small environmental microenterprise, The Green Planet retail store. Exploring two decades of business history it analyses the development of this business as sustainability issues and greener consumer goods mainstreamed in society. The case presents one of the first explorations of the individual tradeoffs that owners make between economic, environmental and social criteria, alongside an exploration of the role that the personal values of the owner played in the evolution of this business. Also presented is a sample of other environmental enterprises profiled alongside The Green Planet in the early 1990s. This additional dataset provides a rich resource for readers, and a number of indicative discussion themes are identified. Readers interested in topics such as marketing, business strategy, innovation, entrepreneurship, corporate social responsibility and environmental management will find this case a valuable addition to their teaching resources.
\end{abstract}

\section{Acknowledgements}

I would like to acknowledge the financial support for this research study provided by the Nuffield Foundation Small Grant Scheme (SGS/37471), and the German Federal Ministry for Education and Research (SEABUS; grant number 01UT1005). I also gratefully acknowledge the assistance of all those who participated in the interviews, and especially Ms Annabelle Ship of The Green Planet. The views expressed here reflect those of the author only.

\section{Introduction}

Annabelle Ship opened The Green Planet store on July $9^{\text {th }} 1990$ in Newton, Massachusetts USA. She recently celebrated their 20-year anniversary but whilst the store name remains the same the nature of the business has changed dramatically since she first opened. Currently The Green Planet retail store has 7500 different stocking codes, a quarter of which are books, with all products focused on children. This teaching case explores the evolution of the business from a store selling speciality 'green products' for the home and garden to a children's toy store, and examines the various strategic decisions and trade-offs the founder had to make as her business (and business model) evolved.

The objectives of the case are twofold: firstly to explore the personal journey of founder of the The Green Planet micro-enterprise, focusing on their recollections of the key business developments, and secondly, to facilitate classroom discussion by providing background data and additional examples of companies operating in 1991. 


\section{Background to the case}

The 1990s saw the emergence of the business case for sustainability (Saunders, 1991), and a recognition of the entrepreneurial opportunities in the emerging niche industries for environmental and, more recently, ethical (including humane, fair trade or social justice) consumer goods and services (Bennett, 1991; Berle, 1991). By 2009, the UK ethical consumerism market was estimated at $£ 43.2$ billion, with average spending per household of $£ 764$, a threefold increase from 1999 (see Table 1 for examples of the kinds of goods and services now considered as ethical, including those with social and environmental dimensions). Despite the recession starting in 2008, demand for products with an eco-friendly, natural, organic, local, humane, or fair trade designation increased in 2009, with sales of almost $\$ 38$ billion in US supermarkets (Packaged Facts, 2009; see also Bastin and Ellis, 2010).

Mass market outlets such as supermarkets now sell 35\% of total retail dollar sales in ethical grocery products in the USA (Table 2) and each year it is estimated that 2100 products are launched that claim ethical credentials (Packaged Facts, 2009).

However in the late 1980s this demand for 'greener', more environmentally responsible consumer products was still in its infancy, with bestsellers like the Green Consumer Guide helping identify green products for the individual shopper due to their lack of availability in mainstream stores (Elkington and Hailes, 1988). Many pioneering entrepreneurs of this period set up small businesses to respond to this emerging demand and the changing regulatory climate. In 1991, Stephen Bennett and Gustav Berle, both independently profiled best practice examples of such 'green' entrepreneurial opportunities and the business models that were emerging at that time. Lober (1998, p.26) defines this process as environmental entrepreneurship, creating 'new products, services or organizations to meet environmental market opportunities'.

More recently, market opportunities for new entrants offered by the sustainability agenda are discussed by Cohen and Winn (2007) and Rogers (2010). These types of enterprise are known by a variety of terms, including ecopreneurial or green-green businesses, environmental entrepreneurship, enviropreneurship or green entrepreneurship (see Bennett, 1991; Isaak, 1997; Menon and Menon, 1997; Lober, 1998; Schaper, 2002; de Bruin and Lewis, 2005; Schaltegger, 2005; Schaper, 2005). The boundaries between eco-friendly and 'ethical' products and services have blurred. In the early 1990s, the focus was mostly on those that had lower environmental impacts or used recycled resources from post-consumer waste, whereas ethical now typically refers to products and services with environmental or social attributes (see Table 1; Co-op, 2010). 
Table 1. Ethical consumer goods market in UK 2003-2009 (adapted from Co-op, 2010, 2005)

\begin{tabular}{|c|c|c|c|c|c|c|c|}
\hline & 2003 & 2007 & 2009 & & 2003 & 2007 & 2009 \\
\hline & $£ m$ & $£ \mathrm{~m}$ & $£ \mathrm{~m}$ & & $£ \mathrm{~m}$ & $£ \mathrm{~m}$ & $£ m$ \\
\hline Ethical Food \& Drink & & & & Eco-travel and Transport & & & \\
\hline Organic & 1,015 & 1,982 & 1,704 & Public transport & 348 & 475 & 560 \\
\hline Fairtrade & 92 & 458 & 749 & Responsible tour operators & 92 & 107 & 111 \\
\hline Rainforest Alliance & $\mathrm{n} / \mathrm{a}$ & $\mathrm{n} / \mathrm{a}$ & 1,076 & Environmental tourist attractions & 19 & 20 & 19 \\
\hline Free range eggs & 188 & 314 & 447 & Green cars $^{1}$ & $22^{* *}$ & 222 & 370 \\
\hline Free range poultry & $\mathrm{n} / \mathrm{a}$ & 130 & 174 & Bicycles $^{1}$ & & 600 & 665 \\
\hline Farmers' markets & $\mathrm{n} / \mathrm{a}$ & 220 & 220 & Travel boycotts * & 1,040 & 817 & 1,022 \\
\hline Vegetarian products & 613 & 758 & 780 & Ethical Personal Products & & & \\
\hline Freedom foods & $\mathrm{n} / \mathrm{a}$ & 28 & 122 & Ethical clothing & 33 & 103 & 177 \\
\hline Sustainable fish & $\mathrm{n} / \mathrm{a}$ & 70 & 178 & Ethical cosmetics & 186 & 371 & 486 \\
\hline Food and drink boycotts $*$ & 1,857 & 1,144 & 1,040 & Charity shops & 270 & 210 & 340 \\
\hline Green Home & & & & Buying for re-use - clothing & $\#$ & 360 & 387 \\
\hline Energy efficient electrical appliances & 1,102 & 1,888 & 1,907 & Clothing boycotts* & \# & 338 & 399 \\
\hline Energy efficient boilers & $\mathrm{n} / \mathrm{a}$ & 1,794 & 2,005 & Real nappies & $\mathrm{n} / \mathrm{a}$ & 4 & 3 \\
\hline Micro-generation & 5 & 32 & 51 & Ethical Finance & & & \\
\hline Green mortgage repayments & 162 & 404 & 418 & Ethical banking & 4,447 & 6,287 & 9,083 \\
\hline Energy efficient light-bulbs & $\mathrm{n} / \mathrm{a}$ & 41 & 40 & Ethical investment & 4,214 & 8,907 & 9,535 \\
\hline Ethical cleaning products & 11 & 38 & 40 & Credit unions & 366 & 465 & 579 \\
\hline Sustainable timber and paper & 704 & 1,019 & 1,417 & Ethical share holdings & $\mathrm{n} / \mathrm{a}$ & 63 & 78 \\
\hline
\end{tabular}




\begin{tabular}{|c|c|c|c|c|c|c|c|}
\hline Green energy & $\mathrm{n} / \mathrm{a}$ & 212 & 306 & Community & & & \\
\hline Rechargeable batteries & $\mathrm{n} / \mathrm{a}$ & 48 & 41 & Local shopping & 1,724 & 2,135 & 2,233 \\
\hline Buying for re-use - household products & \# & 1,064 & 866 & Charitable donations & 2,132 & 3,349 & 3,594 \\
\hline Buying for re-use & 1,443 & \# & \# & Grand Total & 22,358 & 36,477 & 43,223 \\
\hline Ethical boycotts- other $*$ & 85 & \# & \# & & & & \\
\hline
\end{tabular}

Key:

*Boycotts are campaigns to avoid purchasing from named companies in protest against specific practices or their stance on certain issues (see

http://www.ethicalconsumer.org/Boycotts/aboutboycotts.aspx)

** Originally one category and subsequently split

\# data collected in 2003 but changed category and adapted (buying for reuse became household and clothing)

$\mathrm{n} / \mathrm{a}$ data not collected in that year

${ }^{1}$ Described as environmentally friendly transport in 2003 
In the early 1990s the idea of simultaneously achieving economic, social, and environmental sustainability was enthusiastically promoted, a notion which became known as the 'win-win' paradigm of sustainability. However, recent discussions suggest that "trade-offs and conflicts between economic, environmental and social aspects in corporate management and performance represent the rule rather than the exception" (Hahn et al. 2010, p. 218). The need to explore these trade-offs between these three competing dimensions is also discussed by Margolis and Walsh as they call on scholars to "clarify the competing considerations, probe what gives them weight, and explore their relationship" (2003, p. 284). Trade-offs faced by individuals have, to date, received little explicit attention, although organisational behaviour with regard to sustainable development often depends on the perceptions, motives, values and decisions of single actors (Hahn et al., 2010, p. 221).

Furthermore, research on the intersection between entrepreneurship and sustainable development remains limited (see Hall et al., 2010), especially when considering the decisions of individual green entrepreneurs. Whilst there is increasing discussion on greening smaller enterprises (Perez-Sanchez et al., 2003; Nawrocka, 2008; Roy and Thérin, 2008; Retolaza et al., 2009), there is little research on green micro-enterprises, especially their longitudinal evolution. Yet the social, political and regulatory climate has shifted significantly, with an unprecedented rise in media coverage of sustainability issues since 1990 (Holt and Barkemeyer, 2010; Barkemeyer et al., 2009), and this surely must have played a role in the increased demand for greener products and services. As these markets have increased, as evidenced by increased total retail spending (Table 1), the types of outlets in which these products are now found (Table 2) also suggest that they have gone more mainstream.

Table 2. Percentage of total retail dollar sales of ethical grocery products in USA across various channels (adapted from Packaged Facts, 2009)

\begin{tabular}{|l|c|l|}
\hline Channels & Percentage & Details \\
\hline $\begin{array}{l}\text { Natural foods } \\
\text { stores }\end{array}$ & $45 \%$ & $\begin{array}{l}\text { National speciality chains such as WholeFoods and Trader } \\
\text { Joe's, as well as regional chains and independent natural food } \\
\text { stores. }\end{array}$ \\
\hline $\begin{array}{l}\text { Mass-market } \\
\text { channel }\end{array}$ & $35 \%$ & $\begin{array}{l}\text { Conventional supermarkets, chain drugstores and mass } \\
\text { merchandisers. }\end{array}$ \\
\hline $\begin{array}{l}\text { Prestige/ pop } \\
\text { prestige stores }\end{array}$ & $6 \%$ & $\begin{array}{l}\text { Health and beauty care (HBC) specialty store chains, } \\
\text { cosmetic departments and boutiques in department stores, } \\
\text { salons and spas. }\end{array}$ \\
\hline Other retail & $14 \%$ & $\begin{array}{l}\text { Bookstores (e.g. Borders Books); home improvement and } \\
\text { hardware stores (e.g. Home Depot); home specialty (e.g. Bed, } \\
\text { Bath \& Beyond); office supply chains (e.g. Staples); farmers' } \\
\text { markets and community supported agriculture (CSAs) } \\
\text { ventures; and mail-order and Internet sales. }\end{array}$ \\
\hline Total & $\mathbf{1 0 0 \%}$ & \\
\hline
\end{tabular}

The best practice books by Bennett (1991) and by Berle (1991) identified a sample of 223 'green' enterprises operating in 1991. These enterprises form the basis of a wider study on how green businesses have evolved over the last twenty years (see Holt, 2011). Of this original sample, 95 companies have vanished in the intervening two decades, suggesting they never survived the start-up phase (Table 3). A further 40 were either sold or failed, leaving 88 still trading. In the next stage of this on-going research,some of the founders of these enterprises will be interviewed. 
Table 3. Business status in 2010 of sample of environmental enterprises initially profiled in 1991

\begin{tabular}{|l|c|c|}
\hline Business status & Number of businesses & Percentage \\
\hline Sold & 26 & $12 \%$ \\
\hline Failed & 14 & $6 \%$ \\
\hline Not found/status unclear & 95 & $43 \%$ \\
\hline Subtotal & 135 & $61 \%$ \\
\hline Currently trading & 88 & $39 \%$ \\
\hline Total & $\mathbf{2 2 3}$ & $\mathbf{1 0 0 \%}$ \\
\hline
\end{tabular}

A series of exploratory interviews were conducted in August 2010 with six founders. The founders interviewed were contacted based on two factors. Firstly, that they are located in one region (New England) to facilitate logistical planning. Secondly, that they represent a range of sectors including solar, food, waste management and lighting. They include retailers, wholesalers, manufacturers and public services. All the businesses (or product offering) are still operating in some form but one has been sold, and in another the founder has retired. Interviews used a semi-structured interview format, and focussed on the founders' recollections of the history of their business, the decisions they made and the various trade-off decisions made during the development of the enterprise.

For this teaching case, I profile The Green Planet retail store as this is the smallest of the organisations profiled, the one closest to the general public and the one that has been most affected by the mainstreaming of green products.

\section{The Journey of the Retail Store "The Green Planet"}

\section{Business opportunity recognition and market growth}

The founder of The Green Planet, Annabelle, reflects on the early days of The Green Planet, describing how she first identified the business opportunity for a green products retail store. As noted in the literature, a process of "opportunity recognition" (Lumpkin et al., 2004) is used by entrepreneurs to identify potential business opportunities. Media coverage is considered a key component of mainstreaming sustainability and promoting these market opportunities (Barkemeyer et al. 2009).

"It was just around 1990, the $20^{\text {th }}$ anniversary of the original Earth Day, and so the media was obsessed with eco-friendly everything - the whole society was and every time I picked up a newspaper or a magazine or turned on TV or radio there was something else about it on."

Struggling to find products she could use herself, she believed that a market existed for a place to purchase eco-products, and that she might play a role in selling these products to consumers.

"I had a lot of chemical sensitivities and was very conscious of everything I was using on my body, everything that was in the house, everything that I ate, and was trying to live as chemical free a life as possible and that interest kind of merged with the whole eco-friendly approach and I had this idea to open a store that sold eco-friendly products." 
The difficulty she found in identifying a place to buy such products was not surprising. In the early 1990s, the market for green products was still in its infancy with the majority of products sold by independent sellers or specialist outlets. Without widespread access to the internet, consumers relied on green consumer shopping guides (e.g. Elkington and Hailes, 1988) and desk-based research. Spending hours on the phone, Annabelle researched her eco-products, buying small quantities to sell at street fairs. Supporting herself by teaching music, she identified an available shop unit and negotiated a low rent with the landlord. She bought a rug for the floor, painted the walls green, bought wooden bookshelves, and in 1990 opened one of the first green products stores in the USA.

As Table 1 illustrates, there was a wide range of 'greener' products available by 2010 ; in 1991, however, availability was very limited.

"My first products were compost bins, energy efficient lights bulbs, a lot of children's things like inflatable globes and books about how you could save the earth ... and Tshirts made out of organic cotton. I had so few products, I actually had to buy plants to put in between the shelves to make it look fuller."

Yet by 1995, she estimates there were more than 250 retail stores with 'green' in their name, selling different types of environmental products. This growth in the wider market for ethical and environmental goods is described in the annual green consumer reports published in the UK (see Table 1); it also reflects the increasing discourse on sustainability and environmental topics in society (Barkemeyer et al., 2009).

In the mid-1990s, Annabelle was approached by a regional grocery store chain wanting to incorporate some of her knowledge and skills on eco-products into their new chain of stores. An agreement was reached, with the result that Annabelle sourced companies that produced eco-products, bought in bulk and then provided wholesale services to the chain.

"I sourced a company that was manufacturing eco-friendly house cleaning products, dishwasher liquid and laundry soap, and then I would just bottle it in-house with my own label and I would resell it. Same with ... wooden toys; I'd buy them in large quantities, repackage them very simply with recycled tags or rubber bands, and then I'd barcode everything so they'd be ready for the grocery market and then I would sell them."

This wholesaling part of her business grew rapidly, and by 2001 she was supplying a large number of stores around the Boston area. However, when the regional grocery chain was sold to a larger company who then required her to order through a distributor, her profit margins dropped. She was also beginning to sell her products nationally, to a specialised ethical/green supermarket chain. At this point, Annabelle ran her retail outlet and the growing wholesale business and deciding to focus her efforts on just one she was faced with the choice of which business to concentrate on.

\section{Redefining The Green Planet business model}

Reflecting on what meant the most to her Annabelle decided to walk away from the wholesale opportunities and refocus on her independent retail store. However, the trend of green products mainstreaming into supermarkets and other large mainstream outlets was continuing. Specialised national chains like Whole Foods were growing rapidly, selling natural and organic food products and a range of environmentally friendly goods alongside these, including light bulbs and cosmetics. Home and gardening stores were also stocking more green products, such as fertilisers and composting equipment (see Table 2). 
The increasing demand for green products (for trends in the UK, see Table 1) and the widening distribution channels (see Table 2) led to an increasingly complex business environment for a single retail store like Annabelle's specialising in green products. Competitive margins were squeezed as alternative distribution channels were able to undercut prices, and as customers no longer had to visit a specialised store, but could pick up green items in the larger chains alongside their weekly grocery shopping.

"I constantly had to stay ahead of myself ...energy efficiency light bulbs now they are available at... all the major department stores. Compost bins - now the city is selling/giving them."

As the larger supermarkets and home stores began to stock these ethical and environmental products, she shifted to products such as organic cotton to replace her previous lines, but she suffered from supply problems with these.

"So I started selling organic clothing... great ...went really well for a while ... (but then the) companies (started) failing. So I'd put an order in, supposed to get my delivery in May - the things don't show up, half the order shows up in August."

Many of the companies supplying Annabelle were themselves small businesses, suffering from typical start-up problems. Estimates of small firm survival vary from $56 \%$ failing within the first 4 years (Knaup, 2005), or 51.8\% within five years (Dun and Bradstreet, 1989). Others report more positive statistics, with only $28 \%$ of independent firms and $35 \%$ of franchisees failing over a four year period (Bates, 1995). Typically any small and medium enterprises suffer from a range of constraints related to finance, access to markets and lack of access to resources (Perez-Sanchez et al., 2003).

Conditions in the macro environment were also influential, with increasing trends for manufacturing to move overseas. The trade-offs consumers were being asked to make between the environmental attributes of domestic organic cotton and the extra financial costs of this became too extreme.

"The price of non-organic clothing dropped because everything started being ...manufactured overseas in mostly China, Honduras ... So now the cost of domestically made organic cotton was so inflated... that I couldn't sell that clothing at a regular price anymore, so I had to constantly stay ahead.

By early 2002, Annabelle found herself having to reconsider the market again. During the aftermath of the 2001 recession in the USA, Annabelle was faced with a shrinking retail business, even as her range of products became increasingly available in mainstream outlets (Table 2). With the retail business "still shaky" after 9/11 and the closeout of her wholesale business, Annabelle took advantage of her two floors of shop space to turn the top floor into a yoga studio - she even went as far as to train as a children's yoga teacher. However, the key issue she still faced was how to address the changing market for the goods she sold in her retail store.

"I had just finished closing out the wholesale ... now I've lost all the practical (items). All the household products are being sold at Whole Foods and those big chains and I can't compete with their price or selection. All of the compost bins and all those things are gone, all of the hardware stuff has gone, what's left? Clothing? No-one's buying it, because it is too expensive and you can't find it." 
Having lost the majority of the original stock items she began with in 1990, Annabelle identified two remaining product types in her store - gifts and toys.

“What I was left selling at that point was 'gifty' stuff. I didn't want to sell gifts. First of all it is not satisfying. Secondly you have to reinvent yourself literally every four months because (when) the grownups come in ...they don't want the gifts they saw 4 months ago. So then I looked around... what's selling really well, what's interesting that I feel will have an impact on the world? It's kids stuff - kid's products... I always had 20\% of my stock for kids. So I started focusing on that, and little by little changed my whole stock."

It is clear from this narrative that Annabelle placed great emphasis on the impact her products had, and how satisfying selling them made her feel. However, there were challenging trade-offs to be made in deciding which products she would and would not sell.

"I tried selling only very, very pure products. I tried selling all unbleached organic cotton clothing, all natural wooden toys and ...I still couldn't make it go. So I started slowly opening up my standards."

So from 2003 onwards, The Green Planet focused on stocking children's toys and products. Annabelle still maintains tight control over what is sold in her store using a set of personal ethical (environmental and social) criteria to determine what she stocks. She concentrates on how to make her store 'green,' but also successful, detailing her recipe for her product mix.

"As much natural fibre as possible, wood and cloth. Some plastic because you can't have a bath toy made of wood or cloth... But again... 'how much can I get that's recycled'...I don't sell plastic for babies as I don't believe they should have plastic in their mouth... So I slowly relaxed my standards, but in a way that I felt ...was still as green as possible."

She estimates that about $80 \%$ of her stock has some association with a 'green' or ethical attribute, including educational products that teach children about the natural environment. She also believes that it is getting easier to find green products as more companies are using recycled materials. So whilst the mainstream household and energy products are being stocked at supermarkets, she finds that she has greater choice in stocking specialised products.

“There's ... green science products, there's the green toy company making ... all the puzzles from recycled material, all the organic cotton, all the natural wood for toys, all the organic stuffed animals...it's getting easier."

Rising public awareness of environmental and social issues also helps to promote the products her customers buy. Latest research suggests that during the 2008 recession, green products maintained a healthy and growing market share (Co-op, 2010), with customers choosing to pay a green premium.

"There's much more awareness by the customer, the consumer, so they'll buy the products, they'll pay a little bit extra for it to be made out of recycled plastic, whereas even 4 years ago they wouldn't."

As her previous eco-products transitioned into Wal-Mart, Home Depot and other outlets, Annabelle constantly had to innovate and search for the next green product not already 
available through mainstream sources. In her current business model, it is not the products that change dramatically over time, but her customers, the children.

"Children change, every 6 months they are at a different developmental stage, even (every) three months .... So if you start shopping at my store with an infant then... they are 6 months old... now they are a year old... you are looking at different parts of the store. So I find a product that's eco-friendly that I think is wonderful, that sells well, I am going to be able to sell it for 10 years because the next time someone comes in...it's a whole different family - it's a different child. ... I can keep the same products on the shelffor a lot longer."

Annabelle also feels very strongly about giving back to the community. One of her recent initiatives is a free lead-testing service she offers twice a year. She had all products in her store tested by a testing centre in Boston and found 15 to contain banned levels of lead. Hers was the only store in the country to do this at the time, and she even offered this service for products not bought in her store.

"We were on the front page of the Globe, we were on TV, we got a phenomenal amount of publicity and then we also ran, every month or two, public events where people could bring in things they'd purchased from other stores, things they'd inherited, or they'd bought on their trip to Mexico."

Annabelle does not charge for this service, trading off the economic costs against the social value this brings to her local community. However, she does reap some economic benefits: customers trust Annabelle's products to be non-toxic, something which was especially important during the aftermath of Mattel's massive product recall in 2007, prompted by the high lead concentrate paint used by a Chinese subcontractor.

Other community initiatives include free events, such as multi-cultural holidays, the annual Earth Day, and 'seedling days,' where children pot up seeds for their own home gardens. Her yoga space is remains useful: she rents it out to a music teacher and uses it to host author events and birthday parties as " $a$ way to bring the community in". At the time of the interview, she did not hold yoga classes, concentrating instead on staffing the retail store.

Annabelle struggles with finding staff that meets her exacting standards for customer care, one of the key factors to which she attributes her 20 years of success. Customer service and treating people with respect is a critical component of Annabelle's personal and business philosophy. She has a store policy that customers cannot be served if they are talking on the phone, and she expects equal consideration from her staff: they are to welcome each person into the store and pay attention to the customer whilst there, rather than chatting with other staff members.

"It's all part of the whole thing. How we treat each other - it's all part of this whole movement ... it's all about getting back to the basics of how life should be."

\section{Defining success and making trade-offs}

During the evolution of her business, Annabelle made a series of strategic business choices in order to maintain a healthy, profitable business. She also clearly 'values' her business in terms that go beyond purely economic criteria. She articulates the trade-offs she makes between the expansion of her business and the personal satisfaction she gets from the 'way' she operates her business. 
"I am not interested in becoming an enormous business. I really like the mom and pop... I am not trying to make millions of dollars. I am trying to make a nice living ... I think there's still a lot of room for people to say I am going to do this in this neighbourhood, I am going to focus on this community and to succeed. I think a lot of businesses go out because they are too ambitious. They get their ego behind it and they want to become this giant... multi-chain."

The focus on business growth as a measure of success is another aspect she questions. Annabelle is quite happy as the owner/manager of a micro-business.

"They do teach them in business schools that you have to grow or you perish. I don't think you have to 'grow or you perish' - I think you have to change. You don't have to grow - you have to listen to your customers and see what they need. You can't just decide this is what I want to do, no matter what. What I decided was that I was going to be a business person - I was going to do 'that' - with an eco-friendly focus ... but I would see what was selling and adapt."

Perhaps the ultimate trade-off that society will have to consider is whether economic wealth is traded off against environmental and social value, a theme that emerges in the 'prosperity without growth' debate (Jackson, 2009). Annabelle has chosen to make 'enough' profit and gain non-tangible value from other aspects of her business, rather than to try and maximise profit by choosing a wholesale business or a different product mix. Anderson (1998) describes this as gaining 'internal value' associated with concepts such as satisfaction, for instance a 'moral' satisfaction that develops from the synergy of environmental, societal and entrepreneurial values of the individual.

These post-material values associated with quality of life concerns (Ingelhart and Rabier, 1986; Ingelhart, 1989) are evident in the way Annabelle describes whether she considers herself successful.

"I wouldn't define it as 100\% successful as I haven't figured out how to make the business run without me being there most of the time... I would say I am successful because I am still here 20 years later. I am still in basically the same business. I've managed to maintain my values within that business. I still love what I do. I still get out of bed excited about it. I still get to run my own show, which is very much me. I still get to be creative and that's also a very important part of it. I still get to go to work with my dog... and I basically call the shots in my life. To me that's successful. I make a nice living - I am not wealthy - but I make a decent living."

The evolution of The Green Planet from a specialist eco-products store in 1990 to a speciality children's toy store is a story of incremental change in response to market conditions, and a series of trade-off decisions. The market in which Annabelle set up her store has changed dramatically over two decades. Green products have mainstreamed into large national (and international) chain stores. Small 'mom and pop' micro-businesses face increasingly hostile business conditions, but these businesses also offer unique opportunities for individual development that reflects the personal values of the owner. Entrepreneurs who operate in green/ethical markets make multiple trade-offs between the three dimensions of sustainability, considering economic sustainability, environmental attributes and the social dimensions of their products and business model. This case presents a rare glimpse into the individual trade-offs that entrepreneurs like Annabelle have made in businesses associated with green/ethical retail consumer products. following:

Readers who wish to explore The Green Planet case in more detail might consider the 
- How have changes in the competitive environment shaped the business model and product mix at The Green Planet since 1990?

- Why did Annabelle's business not 'grow'? Consider the concept of business growth with relation to the decisions Annabelle made and the 'prosperity without growth' debate (Jackson, 2009).

- Using appropriate strategic models consider how the The Green Planet product mix developed over the case.

- Consider why Annabelle tested products not bought in her store for lead contamination? Was this a 'good' business decision?

\section{Extending the case study}

The second objective of this case is to extend the discussion and consider other firms who were operating in the early 1990s. Bennett (1991) profiled The Green Planet as one of a number of best practice ecopreneurial companies; along with almost 100 others (see Holt, 2011). Some of these, like the Body Shop and Ecover, have grown into very large enterprises. Of the 223 green enterprises profiled in 1991 by both Bennett and Berle, 43\% have vanished with no evidence remaining online of what happened to them. Unlike The Green Planet, those are likely the micro-businesses that failed, where Annabelle succeeded. Some of the original 1991 enterprises have been acquired, or merged with others, as part of a strategic move to gain access to green products or markets. Readers using this case are invited to explore the business history of the other companies profiled in Appendix 1, especially the strategic role mergers and acquisitions may have played in their development.

This case has focused on a number of trade-offs made by the founder and owner Annabelle during the evolution of The Green Planet. Individual consumers also have to make trade-off decisions every time they make a purchase. These might be explored further using field visits as detailed below.

- Identify a range of specific products that are natural, organic, local, humane, or fair trade. Do these have an environmental and/or social attribute? Consider how consumers may need to make trade-off decision regarding environmental criteria compared with those considered social issues (after Holt and Watson, 2008).

- Think about your recent purchases. What trade-offs are you prepared to make when purchasing goods and services in relation to social, environmental or economic factors?

The market for products that consider environmental and/or social dimensions continues to grow, as evidenced by the steady growth in retail spending tracked by the annual Ethical Consumerism reports (e.g. Co-op, 2010), alongside the increasing market opportunities for new business start ups (Cohen and Winn, 2007; Rogers, 2010). This case presents a unique historical perspective on the experiences of a pioneer green entrepreneur, and offers insights that might be of value to the new generation of entrepreneurs riding the latest wave of interest in social and environmental sustainability.

\section{References}

Anderson AR. 1998. Cultivating the Garden of Eden: environmental entrepreneuring. Journal of Organizational Change Management, 11(2): 135-144.

Barkemeyer R, Figge F, Hahn T, Holt D. 2009. What the papers say - trends in sustainability. Journal of Corporate Citizenship 33(Spring): 69-86.

Bates T. 1995. Analysis of survival rates among franchise and independent small business startups. Journal of Small Business Management 33(2): 26-36

Bennett S J. 1991. Ecopreneuring- the complete guide to small business opportunities from the environmental revolution. Wiley: New York. 
Berle G. 1991. The green entrepreneur: Business opportunities that can save the earth and make you money. Blue Ridge Summit, PA: Liberty Hall Press.

Cohen B, Winn, MI. 2007. Market imperfections, opportunity and sustainable entrepreneurship. Journal of Business Venturing 22(1): 29-49.

Co-op. 2005. Ethical Consumerism Report 2005. Manchester: The Cooperative Bank Plc.

Co-op. 2010. Ethical Consumerism Report 2010. Manchester: The Cooperative Bank Plc.

de Bruin A, Lewis K. 2005. Green entrepreneurship in New Zealand: A micro-enterprise focus. In M. Schaper (Ed.), Making ecopreneurs: Developing sustainable entrepreneurship. Hampshire: Ashgate; 61-70.

Dun \& Bradstreet. 1989. Business Failure Record. New York: Dun \& Bradstreet.

Elkington J, Hailes J. 1988. The Green Consumer Guide: From Shampoo to Champagne - Highstreet shopping for a better environment. Victor Gollancz: London.

Ellis L, Bastin C. 2010. Corporate social responsibility in times of recession: changing discourses and implications for policy and practice. Corporate Social Responsibility and Environmental Management DOI: 10.1002/csr.254

Hahn T, Figge F, Pinkse J, Presuss L. 2010. Trade-Offs in Corporate Sustainability: You Can't Have Your Cake and Eat It. Business Strategy and the Environment 19: 217-229.

Hall JK, Daneke, GA, Lenox, MJ. 2010. Sustainable development and entrepreneurship: past contributions and future directions. Journal of Business Venturing 25(5): 439-448

Holt D. 2011. Where are they now? Tracking the longitudinal evolution of environmental businesses from the 1990s. Business Strategy and the Environment 20(4): 238-250

Holt D, Barkemeyer R. (2010). Media coverage of sustainable development issues - attention cycles or punctuated equilibrium? Sustainable Development, DOI: 10.1002/sd.460

Holt D, Watson A. 2008. Exploring the dilemma of local sourcing versus international development - the case of the flower industry. Business Strategy and the Environment 17 (5): 318-329.

Ingelhart R, Rabier JR. 1986. Political realignment in advanced in advanced industrial society: from class based politics to quality of life politics. Government and Opposition 21(4): 456-79.

Ingelhart R. 1989. Culture Shift. University Press : Princetown NJ.

Isaak R. 1997. Globalisation and green entrepreneurship. Greener Management International 18: $80-90$.

Jackson T. 2009. Prosperity without growth economics for a finite planet. Earthscan: London.

Knaup AE. 2005. Survival and longevity in the Business Employment Dynamics data. Monthly Labor Review Bureau of Labor Statistics May: 50-56.

Lober DJ. 1998. Pollution prevention as corporate entrepreneurship. Journal of Organizational Change Management 11(1): 26-37.

Lumpkin GT. Hills GE, Shrader RC. 2004. Opportunity recognition. In Entrepreneurship the way ahead. Welsch, H.P. (ed). Routledge: London; 73-90.

Margolis J, Walsh J. 2003. Misery loves companies: rethinking social initiatives by business. Administrative Science Quarterly 48: 268-305.

Menon A, Menon A. 1997. Enviropreneurial marketing strategy: The emergence of corporate environmentalism as marketing strategy. Journal of Marketing 61: 51-67.

Nawrocka D. 2008. Environmental supply chain management, ISO 14001 and RoHS. How are small companies in the electronics sector managing? Corporate Social Responsibility and Environmental Management 15(6): 349-360.

Packaged Facts. 2009. Ethical Food and Beverage, Personal Care and Household Products in the U.S.; Conscientious Consumerism and Corporate Responsibility in the New Economy, 2nd Edition. Packaged Facts: Rockville, MD.

Perez-Sanchez D, Barton JR, Bower D. 2003. Implementing environmental management in SMEs. Corporate Social Responsibility and Environmental Management 10(2): 67-77. 
Retolaza JL, Ruiz M, San-Jose L. 2009. CSR in business start-ups: an application method for stakeholder engagement. Corporate Social Responsibility and Environmental Management 16(6): 324-336.

Rodgers C. 2010. Sustainable entrepreneurship in SMEs: a case study analysis. Corporate Social Responsibility and Environmental Management 17(3): 125-132.

Roy MJ, Thérin F. 2008. Knowledge acquisition and environmental commitment in SMEs. Corporate Social Responsibility and Environmental Management 15(5): 249-259.

Saunders T. 1993. The Bottom Line of Green is Black: Strategies for Creating Profitable and Environmentally Sound Businesses. Harper: San Francisco, California.

Schaltegger S. 2005. A framework and typology of ecopreneurship: Leading bioneers and environmental managers to ecopreneurship. In Making ecopreneurs: Developing sustainable entrepreneurship. M. Schaper (Ed.). Ashgate: Hampshire; 43-60.

Schaper M. 2002. The essence of ecopreneurship. Greener Management International, 38: 26.

Schaper M. 2005. Making ecopreneurs: Developing sustainable entrepreneurship. Ashgate: Burlington, VT. 
Appendix 1. Selection of environmental enterprises profiled in 1991 that developed through merger and acquisition activity

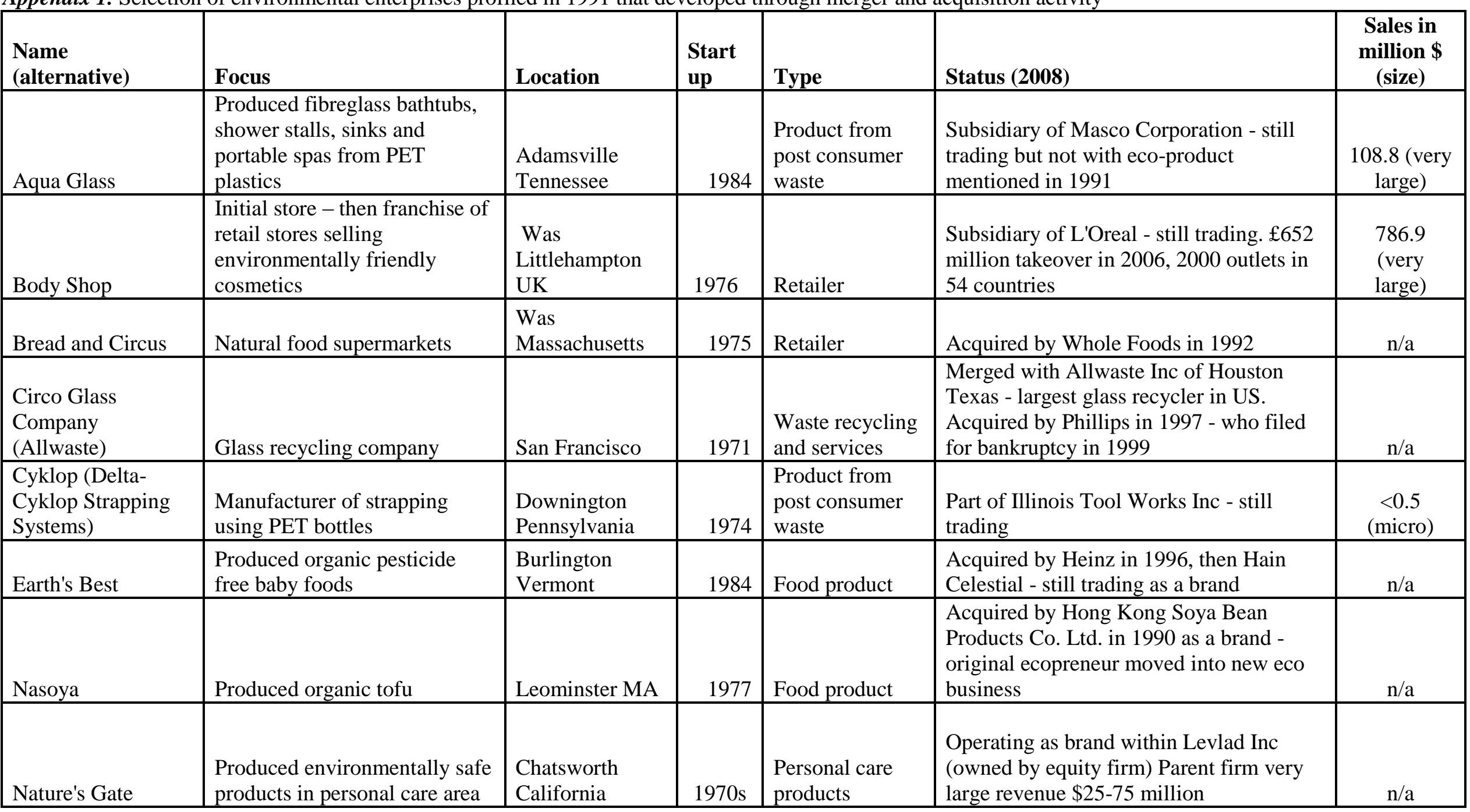




\begin{tabular}{|c|c|c|c|c|c|c|}
\hline $\begin{array}{l}\text { New England } \\
\text { Container Recovery } \\
\text { Inc (CRInc.) }\end{array}$ & $\begin{array}{l}\text { Serviced } 5000 \text { retail accounts } \\
\text { to recycle beverage containers }\end{array}$ & & 1982 & $\begin{array}{l}\text { Waste recycling } \\
\text { and services }\end{array}$ & $\begin{array}{l}\text { Sold to WMX in } 1995 \text { (in liquidation) } \\
\text { assets sold }\end{array}$ & $\mathrm{n} / \mathrm{a}$ \\
\hline $\begin{array}{l}\text { Pride's Corner } \\
\text { Farms }\end{array}$ & $\begin{array}{l}\text { Produce fertilizer (Eathgro) } \\
\text { from agricultural waste and } \\
\text { sewage sludge. }\end{array}$ & $\begin{array}{l}\text { Lebanon } \\
\text { Connecticut }\end{array}$ & 1977 & $\begin{array}{l}\text { Product from } \\
\text { post consumer } \\
\text { waste }\end{array}$ & $\begin{array}{l}\text { Original mention in Bennett as fertilizer } \\
\text { product - Earthgro - this was business was } \\
\text { sold for } \$ 47 \text { million in } 1998 \text { to publically } \\
\text { listed Scotts company. Now trades as a } \\
\text { brand. Prides Corner Farms still operating } \\
\text { successfully. }\end{array}$ & $\mathrm{n} / \mathrm{a}$ \\
\hline $\begin{array}{l}\mathrm{R} \text { W Frookies } \\
\text { Corporation }\end{array}$ & Produced healthy cookie range & $\begin{array}{l}\text { Englewood New } \\
\text { Jersey }\end{array}$ & 1998 & Food product & $\begin{array}{l}\text { Merged with Delicious Brands, which } \\
\text { went public, and then taken over. Part of } \\
\text { assets recovered in } 2000 \text { and trades as a } \\
\text { brand. Original ecopreneur moved to new } \\
\text { eco-business (Cool Fruits) }\end{array}$ & n./a \\
\hline $\begin{array}{l}\text { Real Goods } \\
\text { Trading Company } \\
\text { (Gaiam Real } \\
\text { Goods) } \\
\end{array}$ & $\begin{array}{l}\text { Mail order alternative energy } \\
\text { products }\end{array}$ & Ukiah California & 1978 & $\begin{array}{l}\text { Home and } \\
\text { Garden Products }\end{array}$ & $\begin{array}{l}\text { Was bankrupt in } 1986 \text { - reorganised and } \\
\text { recovered. Founder is president. Is a } \\
\text { wholly owned subsidiary of Gaiam since } \\
2001 \text { (sales of } \$ 200+\text { million per year) }\end{array}$ & 19.4 \\
\hline $\begin{array}{l}\text { Ringer Corporation } \\
\text { (Verdant) }\end{array}$ & $\begin{array}{l}\text { Produced insecticides with all } \\
\text { natural ingredients, sold } \\
\text { composting tools and mail } \\
\text { order gardening suppliers } \\
\end{array}$ & Minneapolis & 1989 & $\begin{array}{l}\text { Home and } \\
\text { Garden Products }\end{array}$ & $\begin{array}{l}\text { Rebranded to Verdant, acquired number } \\
\text { of companies, listed. Delisted } 1991 \text { and } \\
\text { assets broken up }\end{array}$ & $\mathrm{n} / \mathrm{a}$ \\
\hline $\begin{array}{l}\text { Sobek Expeditions } \\
\text { (Mountain Travel } \\
\text { Sobek) }\end{array}$ & $\begin{array}{l}\text { Outdoor Adventures - } \\
\text { Ecotourism - used guidelines } \\
\text { for interaction with indigenous } \\
\text { peoples }\end{array}$ & $\begin{array}{l}\text { Angels Camp } \\
\text { California }\end{array}$ & 1973 & Tourism & $\begin{array}{l}\text { Merged with Mountain Travel in } 2001 . \\
\text { Original founders moved on }\end{array}$ & (medium) \\
\hline Solar Works Inc & Installed solar systems & $\begin{array}{l}\text { Montpelier } \\
\text { Vermont }\end{array}$ & 1980 & $\begin{array}{l}\text { Renewable } \\
\text { energy systems }\end{array}$ & $\begin{array}{l}\text { Merged to form Alteris in } 2008 . \\
\text { recapitalised by private investment in } \\
1995\end{array}$ & 9 (medium) \\
\hline Tom's of Maine & $\begin{array}{l}\text { Set up to produce toothpaste, } \\
\text { shampoo and deodorant with } \\
\text { all natural ingredients, } 1982\end{array}$ & Kennebunk & $\begin{array}{l}\text { Early } \\
1970 \mathrm{~s}\end{array}$ & $\begin{array}{l}\text { Personal care } \\
\text { products }\end{array}$ & $\begin{array}{l}\text { Now independently run division within } \\
\text { Colgate-Palmolive Company. Founder } \\
\text { still involved }\end{array}$ & $\begin{array}{c}25 \\
\text { (medium) }\end{array}$ \\
\hline
\end{tabular}




\begin{tabular}{|c|c|c|c|c|c|}
\hline & expanded into mass market & & & & \\
\hline $\begin{array}{l}\text { Trimax Lumber } \\
\text { (Trimax Building } \\
\text { Products Inc) }\end{array}$ & $\begin{array}{l}\text { Produced plastic lumber for } \\
\text { construction }\end{array}$ & $\begin{array}{l}\text { Lincoln Park } \\
\text { New Jersey }\end{array}$ & $\begin{array}{l}\text { Product from } \\
\text { post consumer } \\
\text { waste }\end{array}$ & $\begin{array}{l}\text { Trimax bought by US Plastic Lumber in } \\
2004 \text { who then went bankrupt. Assets sold } \\
\text { to private investor who renamed USPL } \\
\text { Trimax Building Products Inc }\end{array}$ & $\begin{array}{c}6.8 \\
\text { (medium) } \\
\end{array}$ \\
\hline Tri-R systems & $\begin{array}{l}\text { Conglomerate of five units, } \\
\text { multi-commodity recycling } \\
\text { firm }\end{array}$ & Denver & $\begin{array}{l}\text { Waste recycling } \\
\text { and services }\end{array}$ & $\begin{array}{l}\text { Went public in } 1989 \text {. Filed for Chapter } 11 \\
\text { bankruptcy in } 1990 \text { until 1993. Three of } \\
\text { units sold by March } 1995 \text {. Remaining } \\
\text { elements linked to small firm Dataguard }\end{array}$ & $\mathrm{n} / \mathrm{a}$ \\
\hline
\end{tabular}

